\title{
SULFAPYRIDINE, SULFANILAMIDE, AND SPECIFIC ANTISERUM IN EXPERIMENTAL TYPE III PNEUMOCOCCIC INFECTIONS
}

\author{
By FRANK B. COOPER, PAUL GROSS, AND MARION LEWIS \\ (From The Western Pennsylvania Hospital, Institute of Pathology, Pittsburgh)
}

(Received for publication March 11, 1939)

It has been claimed by Whitby (1) that sulfapyridine saved a majority of mice infected intraperitoneally with 10,000 fatal doses of pneumococci of Types I, II, III, V, VII, and VIII, its therapeutic efficacy being more pronounced against Types I, VII, and VIII. Furthermore, mice which recovered by virtue of this presumably nontoxic drug were immune to a second infection of 10,000 and in some instances $1,000,000$ fatal doses of pneumococci as early as the end of the first week.

The announcement of this experimental work was quickly followed by the clinical report of Evans and Gaisford (2) who claimed a reduction in mortality from 27 in 100 untreated cases of pneumonia to 8 in 100 who received sulfapyridine. These two papers are responsible for the present intense interest in sulfapyridine as an antipneumococcic drug.

A comparison of the efficacy of sulfapyridine and sulfanilamide by Cooper, Gross, and Lewis (3) against Type II pneumococcic infections of less than 100 fatal doses in both mice and rats showed the former compound slightly more effective than the latter, although approximately one-half of the animals in the treated groups died.

In a simultaneous publication, Hilles and Schmidt (4) reported sulfapyridine not significantly superior to sulfanilamide against mouse infections of 100 fatal doses of Type XXII pneumocci. Unfortunately, the results obtained are not comparable because different dosages of the two drugs were administered by two different methods. Although sulfapyridine prolonged the lives of all 20 mice, 9 living 6 days or longer, all but one died before the fifteenth day. Similarly, in the sulfanilamide group, most of the mice died after the sixth day and all by the thirteenth day. In a subsequent experiment, 14 of 20 mice which received $80 \mathrm{mgm}$. of sulfapyridine orally each day for 4 days, then $40 \mathrm{mgm}$. daily for 2 days, survived 30 days. A comparable sulfanilamide experiment was not recorded.
Long, Bliss, and Feinstone (5), on the other hand, concluded that sulfapyridine was considerably more effective than sulfanilamide in the treatment of experimental Type I infections of mice. These conclusions were based on a 12 per cent survival in the sulfapyridine group and no survivors in the sulfanilamide group, both of which were infected with approximately 1180 fatal doses.

Because of the lack of agreement between Whitby's (1) and our own (3) results, experimental work has been continued and the comparative efficacy of sulfapyridine, sulfanilamide, and specific antipneumococcic rabbit serum determined against Type III pneumococcic meningitis and pneumonia of rats as well as septicemia of mice.

The immunity of the recovered animals from this and from a preceding experiment (3) was determined by the intraperitoneal inoculation of 1 and also of 100 fatal doses of homologous culture.

The purpose of the following report is to present the data from this study.

\section{Pneumococcic meningitis of rats}

Method. Six groups of 15 rats each were infected intracranially $(3,6,7,8)$ with a suitable dilution of a broth culture of Strain 420 which was shown by previous and simultaneous intracranial titration to contain 10 fatal doses. This culture was selected because it typed well with therapeutic Type III rabbit serum ${ }^{1}$ and with Type III typing serum but did not cross-type with Type VIII serum.

One group served as untreated controls, while the remaining 5 were treated, as shown in Figure 1 , with sulfanilamide, ${ }^{2}$ sulfapyridine, ${ }^{3}$ Type III antipneumococcic rabbit serum, sulfanilamide plus serum, and sulfapyridine plus serum.

\footnotetext{
${ }^{1}$ Kindly donated by E. R. Squibb \& Sons, New York.

2 Synthesized and donated by the Monsanto Chemical Co., St. Louis, Mo.

${ }^{3}$ Supplied by Merck \& Co., Inc., Rahway, N. J.
} 


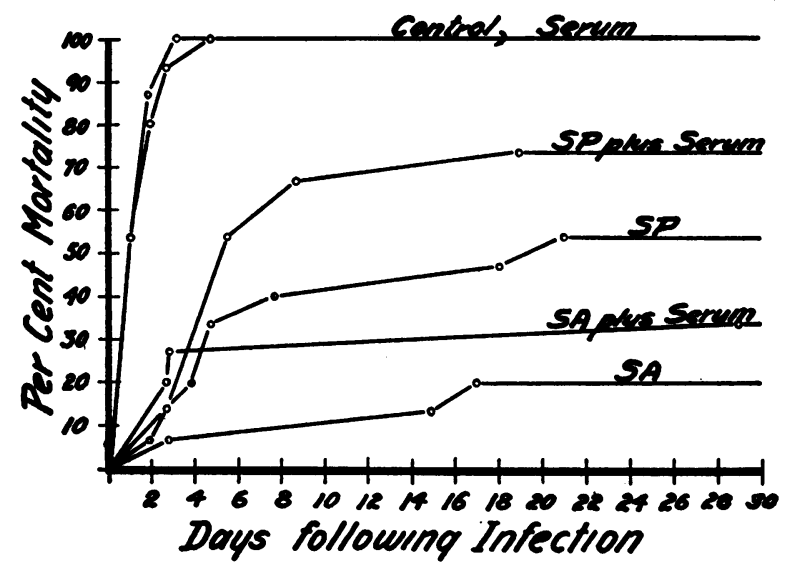

Fig. 1. Meningitis

Mortality curves of rats infected with 10 fatal doses of Type III (Strain 420) pneumococcus and treated 6 hours after infection.

Infection: $0.1 \mathrm{cc}$. of a $10^{-4}$ broth dilution of an 18-hour broth culture intracranially.

Treatment: Controls: 15 rats, no treatment.

SA : 15 rats, $100 \mathrm{mgm}$. of sulfanilamide in $0.5 \mathrm{cc}$. of 15 per cent gum acacia orally 6 hours after infection, then twice daily for 7 days, followed by $100 \mathrm{mgm}$. once daily for 7 days.

SP : 15 rats, same dosage of sulfapyridine.

Serum: 15 rats, 333 units of Type III rabbit antipneumococcic serum intraperitoneally 6 hours after infection, then once daily for 2 successive days (1000 units).

SA plus serum: 15 rats, combination of sulfanilamide and serum therapy used above.

SP plus serum: 15 rats, combination of sulfapyridine and serum therapy used above.

The immunity of the rats which survived for one month was determined by infecting them intraperitoneally with approximately one fatal dose, determined by intraperitoneal titration, of the same Type III strain.

Results. As shown in Figure 1, all untreated rats died in 2 days and all serum-treated rats within 5 days. The sulfanilamide- and sulfapyridine-treated groups suffered a mortality of 3 and 8; the sulfanilamide plus serum and sulfapyridine plus serum groups, 5 and 11 of 15 rats respectively. It is significant that of the 75 rats which received some form of treatment, 6 died late in the experiment of a relatively fresh meningitis.

Of the 32 rats which recovered from meningitis as a result of treatment, 22 failed to survive the intraperitoneal infection of approximately one fatal dose of the same strain of Type III pneumococci one month later. The distribution of casualties in this group was as follows: sulfanilamide, 7 of 11 ; sulfapyridine, 4 of 7 ; sulfanilamide plus serum, 8 of 10 ; and sulfapyridine plus serum, 3 of 4 . These results are comparable to the mortality rate of 7 of the control group of 10 normal rats. Similarly, all 33 survivors from an earlier Type II meningitis experiment (3) died when reinfected, this time intraperitoneally, with less than 10 fatal doses of homologous culture. This infecting dose killed 9 of 10 normal rats.

\section{Pneumococcic pneumonia of rats}

Method. Four groups, each of 15 rats, were infected intratracheally, as described in previous experiments $(9,10,11,12)$ with a mucin suspension of approximately 100 fatal doses of Strain 420 Type III pneumococci. One group received no treatment, whereas the remaining 3 groups were treated with sulfanilamide, sulfapyridine, and Type III antipneumococcic rabbit serum as shown in Figure 2.

Results. Reference to Figure 2 shows that all

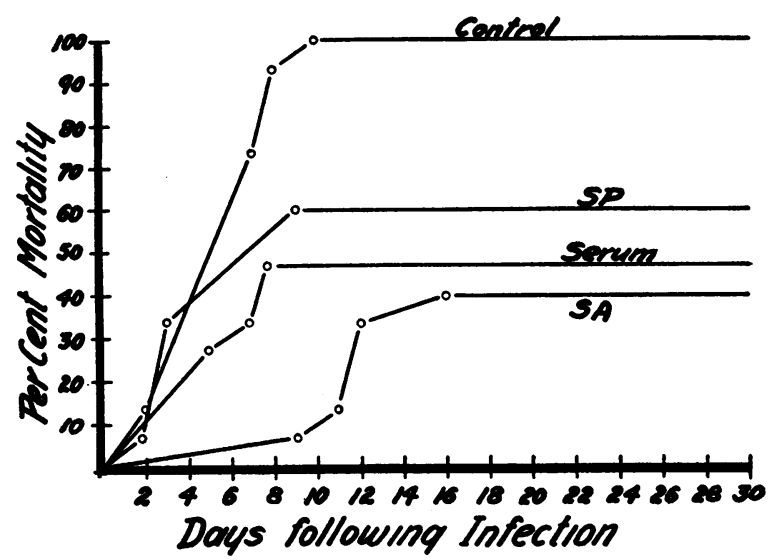

Fig. 2. Pneumonia

Mortality curves of rats infected with 100 fatal doses of Type III (Strain 420) pneumococcus and treated 5 hours after infection.

Infection: $0.15 \mathrm{cc}$. of a mucin suspension of an 18-hour broth culture, diluted $10^{-1}$ intratracheally.

Treatment: Controls: 15 rats, no treatment.

SA : 15 rats, $100 \mathrm{mgm}$. of sulfanilamide in $0.5 \mathrm{cc}$. of 15 per cent gum acacia orally 5,12 , and 21 hours after infection, then twice daily for 5 days, followed by 100 mgm. once daily for 3 days.

SP : 15 rats, same dosage of sulfapyridine.

Serum: 15 rats, 333 units of Type III rabbit antipneumococcic serum intraperitoneally 5 hours, 1 , and 2 days after infection and 500 units on the third day (1500 units). 
control rats died in 2 to 10 days after infection, whereas the mortality of the sulfanilamide, sulfapyridine, and serum-treated groups was 6,9 , and 7 of 15 respectively one month later. All fatalities, except four in the sulfapyridine group, showed at autopsy the type of experimental pneumonia previously described.

Bacteremia, as demonstrated by culture from the femoral vein at autopsy, was present in all control and sulfanilamide-treated rats, but was absent in several serum-treated rats and several treated with sulfapyridine.

In this experiment, as in the preceding one, there were a number of delayed deaths, 5 of which occurred in the sulfanilamide group from 11 to 16 days and one in the sulfapyridine group 9 days after infection.

The immunity of the pneumonia survivals was considerably greater than that of the meningitis survivals since there were only 4 deaths out of 18 survivors distributed as follows : 1 of 8 in the sulfanilamide, 3 of 4 in the sulfapyridine, and none of 6 in the serum group; whereas 11 of 14 normal control rats died.

\section{Pneumococcic septicemia of mice}

Method. Four groups, each of 10 mice, were infected subcutaneously with more than 100 fatal doses of the same 420 strain. (Titration mice which received $1 / 10$ and $1 / 100$ of the infecting dose used in the experiment died within 72 hours.) One group served as untreated controls, while the remaining groups were treated as shown in Table I.

Results. The mortality rates of the various groups were : controls, 10 ; sulfanilamide, 9 ; sulfapyridine, 5; and serum, 5 of 10 mice.

Since the number of survivals from this experiment was too small to be statistically significant, the survivals from some unreported mouse experiments were reinfected intraperitoneally with 100 fatal doses of the homologous Type II (Binda) culture. Reference to Table II indicates the presence of some degree of immunity in the recovered mice.

\section{DISCUSSION}

The above experiments show that equal doses of sulfanilamide or sulfapyridine possess approxi-
TABLE I

Therapeutic efficacy of sulfanilamide, sulfapyridine, and specific antipneumococcic serum against Type III pneumococcic infection of mice*

\begin{tabular}{|c|c|c|c|c|c|c|c|c|c|}
\hline \multirow{2}{*}{ Treatment $\dagger$} & \multirow{2}{*}{$\begin{array}{l}\text { Num- } \\
\text { ber } \\
\text { of } \\
\text { mice }\end{array}$} & \multicolumn{7}{|c|}{$\begin{array}{c}\text { Number of deaths daily } \\
\text { during } 21 \text { days }\end{array}$} & \multirow{2}{*}{$\begin{array}{l}\text { Num- } \\
\text { ber of } \\
\text { fatal- } \\
\text { ities }\end{array}$} \\
\hline & & 1 & 2 & 3 & 4 & 5 & 6 & $7-13$ & \\
\hline $\begin{array}{l}\text { None } \ldots \ldots \ldots \\
\text { Sulfanilamide } \ldots \ldots \ldots \ldots \\
\text { Sulfapyridine } \ldots \ldots \ldots \\
\text { Type III rabbit serum. }\end{array}$ & $\begin{array}{l}10 \\
10 \\
10 \\
10\end{array}$ & 1 & 3 & $\begin{array}{l}6 \\
1\end{array}$ & $\begin{array}{l}1 \\
2\end{array}$ & 1 & $\begin{array}{l}3 \\
1\end{array}$ & $\begin{array}{l}2 \\
3\end{array}$ & $\begin{array}{r}10 \\
9 \\
5 \\
5\end{array}$ \\
\hline
\end{tabular}

* Infection: $0.5 \mathrm{cc}$. of a $10^{-7}$ broth dilution of an 18-hour broth culture (100 fatal doses) of Type III (Strain 420) pneumococcus subcutanéously.

$\dagger$ Treatment: Sulfanilamide: $20 \mathrm{mgm}$. of sulfanilamide in $0.2 \mathrm{cc}$. of 15 per cent gum acacia 3 hours after infection, then once daily for 8 days.

Sulfapyridine: Same dosage as of sulfanilamide.

Serum: 100 units of Type III antipneumococcic rabbit serum intraperitoneally 3,24 , and 48 hours after infection (300 units).

TABLE II

Immunity of recovered mice to reinfection with 100 fatal doses of homologous culture*

\begin{tabular}{|c|c|c|}
\hline$\underset{\text { treatment }}{\text { Previous }}$ & $\begin{array}{c}\text { Number of } \\
\text { mice }\end{array}$ & $\begin{array}{c}\text { Number of } \\
\text { survivors }\end{array}$ \\
\hline $\begin{array}{l}\text { None..... } \\
\text { Sulfanilamic } \\
\text { Sulfapyridin }\end{array}$ & $\begin{array}{rr}\ldots & 26 \\
\ldots & 9 \\
\ldots & 18\end{array}$ & $\begin{array}{c}\text { None } \\
7 \\
6\end{array}$ \\
\hline
\end{tabular}

* Infection: $0.5 \mathrm{cc}$. of a $10^{-7}$ broth dilution of an 18-hour broth culture of homologous Type II (Binda) culture (100 fatal doses).

mately the same therapeutic efficacy against both Type III pneumococcic meningitis and Type III pneumococcic pneumonia of rats. An earlier experiment also showed these drugs to be of approximately equal value in treating experimental Type II pneumococcic meningitis (3). In mice, however, sulfapyridine was superior to sulfanilamide against Type III pneumococcic sepsis in the above experiment as well as Type II sepsis in the previous experiment (3). This is not surprising since the computed efficacies of any 2 drugs which possess approximately the same value may vary somewhat in either direction when different types and strains of pneumococci or animals are used. Although variations of this kind have been attributed to strain $(13,14)$ and to type (4) differences, both the experimental work and the cures of clinical pneumococcic meningitis point to strain difference as the more important factor. This view is strengthened by our experience with 
3 Type II strains which show marked differences in invasive power and in response to chemotherapy. However, experimental results show that neither sulfapyridine nor sulfanilamide is effective against pneumococcic infections of mice or rats when the infection exceeds 100 fatal doses. This statement receives added support from the results of experiments (15) in which mice were infected with approximately 100 lethal doses of Type II pneumococci and treated 4 hours later. An aggregate of 80 mice treated with sulfapyridine suffered a 55 per cent mortality while an equal number of mice treated with an equal dosage of sulfanilamide showed a 74 per cent mortality at the end of 3 weeks. Hilles and Schmidt (4) obtained similar results in mice treated with 4 grams per kilo the first day, followed by 5 daily treatments of 1 gram per kilo; but saved 14 out of 20 mice when 4 grams per kilo were given for 4 days and 2 grams per kilo for 2 additional days.

In view of the discrepancy between the results so far reported and Whitby's (1) claim that sulfapyridine saved a majority of mice infected with 10,000 fatal doses of pneumococci, a further consideration of the method whereby such favorable results were obtained appears indicated. In Whitby's various publications $(1,16,17)$, the therapeutic efficiency of each drug under investigation was expressed by a figure designated as the "survival value." This figure represented the average survival time of groups of mice, usually 6 in number, which were observed in most instances for 7 days. This simple method of evaluation is open to question since it ignores ultimate survivals and may give the same value, such as 5 out of a possible 7, in experiments which produce quite different end results. For example, a value of 5 would be obtained in an experiment in which one-half of the mice survived indefinitely, while 1 of each of the remaining 3 died at the end of the second, third, and fourth days. Similarly, a value of 5 would be obtained if all mice died at the end of the fifth day or if 2 died at the end of each of the fourth, fifth, and sixth days, leaving in the last 2 instances no survivors. The 7-day period of observation, considered adequate by Whitby $(1,16,17,18)$ was found to be insufficient by others who observed a significant number of deaths between the second and fourth weeks of observation $(3,4,9,10,12,19,20,21)$.
Another circumstance which throws doubt upon the validity of this method of evaluation is the difference in values which the author reported for sulfanilamide against Type I infections: 1.2 out of a possible 7 in 1937 (18) and 3.3 out of 7 in 1938 (1).

It is evident from Experiment I that sulfanilamide and sulfapyridine are about equally effective in treating Type III experimental meningitis, whereas Type III rabbit antipneumococcal serum was valueless. However, in Experiment II all three medications appeared equally effective, in the dosages employed, against pneumococcic pneumonia. This latter observation is confirmatory of previous conclusions concerning the therapeutic value of sulfanilamide and specific antiserum in experimental Type I (10) and Type II (12) pneumococcic pneumonia and Type I pneumococcic meningitis (8).

The serum dosage was calculated on a weight for weight basis from a human dosage of 350,000 units for Experiment I, one and one-half times that amount for Experiment II, and three times the amount for Experiment III.

The dosage of sulfanilamide employed throughout was that which has consistently given good results in our hands $(6,7,9,10,11,12)$. The fact that this dosage of 0.5 to 1.0 gram per kilo of rat is, weight for weight, considerably more than the 0.08 to 0.15 gram per kilo generally advocated for man (22), has occasionally prevented the casual observer from recognizing the clinical application of the animal experiments. For example, the Pneumonia Commission of the Medical Society of the State of Pennsylvania (23) was of the opinion that the amount of sulfanilamide required for adequate treatment of clinical pneumonia, calculated from the quantity used in animals, was so great as to be dangerous. Marshall and Cutting (24) have subsequently shown such fears to be groundless since only a fraction of the dose which is required to maintain the therapeutically effective concentration of 5 to $15 \mathrm{mgm}$. per cent in the rat is necessary to produce the same optimum blood level in man. In the mouse, however, 1.0 gram per kilo produced the high concentration of approximately $50 \mathrm{mgm}$. per cent during the first 2 hours, 20 to $25 \mathrm{mgm}$. per cent by the sixth hour and about $6 \mathrm{mgm}$. per cent at the end of 24 hours. A dose of 0.4 gram per 
kilo gave a maximum concentration of $20 \mathrm{mgm}$. per cent the first hour but a concentration of only 4 mgm. per cent within 6 hours (24). From this it is evident that the rat is the experimental animal of choice, not only because of the ease in producing the pneumococcic diseases most frequently encountered in humans, namely pneumonia and meningitis, but, because daily or twice daily treatments produce blood concentrations of sulfanilamide of the same order as those considered optimum in clinical practice. Furthermore, the validity of the results obtained experimentally in rats is being substantiated by the rapidly accumulating reports of clinical cures of both pneumococcic pneumonia and meningitis (8).

The high degree of immunity which Whitby (1) claimed followed the recovery of sulfapyridine-treated mice was absent in our series of meningitis and pneumonia rats which received sulfapyridine. In fact, these rats showed numerically less immunity than those treated with sulfanilamide or serum when reinfected with one or ten carefully titrated fatal doses of homologous culture. It would also appear that late deaths would have been less frequent in both series if a significant degree of immunity had followed treatment and apparent recovery. In regard to the immunity of recovered mice, Feinstone $e t$ al. (25) observed none in those which had received 4,4'diaminodiphenylsulfone, when reinfected 30 days later with 10 to 100 fatal doses. Although our mice showed a certain degree of immunity, it did not approach that claimed by Whitby (1) since 12 of 18 sulfapyridine recoveries and 2 of 9 sulfanilamide recoveries died when reinfected with only 100 fatal doses.

\section{CONCLUSIONS}

1. Sulfanilamide and sulfapyridine ${ }^{4}$ were equally effective against Type III experimental pneumococcic meningitis and pneumonia of rats, whereas

4 While this paper was in press Gross, Cooper, and Lewis (Proc. Soc. Exper. Biol. and Med., 1939, 40, 448) and Antopol and Robinson (Ibid., 1939, 40, 428) simultaneously reported kidney damage due to acetyl-sulfapyridine uroliths in rats fed sulfapyridine. If it were possible to obviate the renal complications in rats treated with sulfapyridine, it would seem likely that the latter drug would prove to be slightly superior to sulfanilamide in the rat as well as in the mouse. sulfapyridine was somewhat superior against Type III pneumococcic sepsis of mice. Neither drug was effective against more than 100 fatal doses.

2. Specific Type III pneumococcic rabbit antiserum was as effective as sulfanilamide or sulfapyridine in Type III pneumococcic pneumonia of rats and more effective than sulfanilamide in sepsis of mice. This serum had no therapeutic action in meningitis of rats caused by the same culture of Type III pneumococcus.

3. The rats which recovered from pneumococcic pneumonia showed a slight immunity which was least marked in those treated with sulfapyridine. No appreciable immunity was demonstrable in the rats which recovered from pneumococcic meningitis irrespective of their previous therapy.

4. Sulfapyridine-treated mice which recovered from pneumococcic sepsis possessed less immunity than sulfanilamide-treated mice. In either group this immunity was not sufficiently great to save all mice reinfected with 100 fatal doses of homologous culture.

\section{BIBLIOGRAPHY}

1. Whitby, L. E. H., Chemotherapy of pneumococcal and other infections with 2-(p-aminobenzenesulfonamido)-pyridine (M\&B 693). Lancet, 1938, 1, 1210.

2. Evans, G. M., and Gaisford, W. R., Treatment of pneumonia with 2-(p-aminobenesulfonamido)-pyridine (M\&B 693). Lancet, 1938, 2, 14.

3. Cooper, F. B., Gross, P., and Lewis, M., Chemotherapeutic evaluation of sulfanilamide and 2(sulfanilamido)-pyridine in Type II pneumococcal infections in mice and rats. Proc. Soc. Exper. Biol. and Med., 1939, 40, 37.

4. Hilles, C., and Schmidt, L. H., Sulfapyridine (2-paminobenzenesulfonamidopyridine) in experimental infections with Type XXII pneumococcus. Proc. Soc. Exper. Biol. and Med., 1939, 40, 73.

5. Long, P. H., Bliss, E. A., and Feinstone, W. H., The effects of sulfapyridine, sulfanilamide and related compounds in bacterial infections. Pennsylvania M. J., 1939, 42, 483.

6. Cooper, F. B., Gross, P., and Lewis, M., Chemotherapy of pneumococcal (Type II) meningitis in the rat. Proc. Soc. Exper. Biol. and Med., 1938, 38, 835.

7. Gross, P., Cooper, F. B., and Lewis, M., The chemotherapy of Type II pneumococcic meningitis. Am. J. M. Sc., 1939, 197, 609.

8. Gross, P., Cooper, F. B., and Lewis, M., Therapeusis of experimental Type I pneumococcic meningitis in rats. Am. J. M. Sc., 1939 (In press). 
9. Gross, P., and Cooper, F. B., Efficacy of p-aminobenzenesulfonamide in experimental Type III pneumococcus pneumonia of rats. Proc. Soc. Exper. Biol. and Med., 1937, 36, 225.

10. Gross, P., and Cooper, F. B., p-aminobenzenesulfonamide and antipneumococcal serum therapy in Type I pneumococcal infections of rats. Proc. Soc. Exper. Biol. and Med., 1937, 36, 535.

11. Cooper, F. B., and Gross, P., para-aminobenzenesulfonamide therapy in experimental Type III pneumococcal pneumonia. Proc. Soc. Exper. Biol. and Med., 1937, 36, 678.

12. Cooper, F. B., and Gross, P., Sulfanilamide, antipneumococcus serum and vitamin $C$ therapy in Type II pneumococcal pneumonia in rats. Proc. Soc. Exper. Biol. and Med., 1937, 36, 774.

13. Rosenthal, S. M., Studies in Chemotherapy. II. Chemotherapy of experimental pneumococcus infections. Pub Health Rep., 1937, 52, 48.

14. Maclean, I. H., Rogers, K. B., and Fleming, A., M\&B 693 and pneumococci. Lancet, 1939, 1, 562.

15. To be published.

16. Whitby, L. E. H., The assessment of the efficiency of chemotherapeutic substances. Practitioner, 1937, $139,650$.

17. Whitby, L. E. H., Chemotherapy of bacterial infections. Lancet, 1938, 2, 1095.

18. Whitby, L. E. H., An experimental assessment of the therapeutic efficacy of amino compounds. Lancet, 1937, 1, 1517.

19. Cooper, F. B., Gross, P., and Lewis, M., Chemotherapy of Types VII and III pneumococcal infections with sulphanilamide, 4,4'-di-(acetylamino)diphenylsulphone and 4,4'-diaminobenzenesulphonanilide. Am. J. M. Sc., 1938, 196, 343.

20. Cooper, F. B., Gross, P., and Mellon, R. R., Action of p-aminobenzensulfonamide on Type III pneumococcus infections in mice. Proc. Soc. Exper. Biol. and Med., 1937, 36, 148.

21. Schmidt, L. H., Use of sulfanilamide in the treatment of Type XIV pneumococcus infections in mice. Proc. Soc. Exper. Biol. and Med., 1937, 37, 205.

22. Long, P. H., Bliss, E. A., and Feinstone, W. H., Mode of action, clinical use and toxic manifestations of sulfanilamide. J. A. M. A., 1939, 112, 115.

23. Pneumonia Commission, Medical Society of the State of Pennsylvania, Weekly Roster and Med. Digest, 1938, 33, 647.

24. Marshall, E. K., Jr., and Cutting, W. C., Absorption and excretion of sulfanilamide in the mouse and rat. Bull. Johns Hopkins Hosp., 1938, 63, 328.

25. Feinstone, W. H., Bliss, E. A., Ott, E., and Long, P. H., Observations concerning the toxicity, absorption and therapeutic effect of sulfanilamide and certain related organic sulphur-containing compounds in experimental infections in mice. Bull. Johns Hopkins Hosp., 1938, 62, 565. 